Reviews

Бәяләмә һәм күзәтүләр

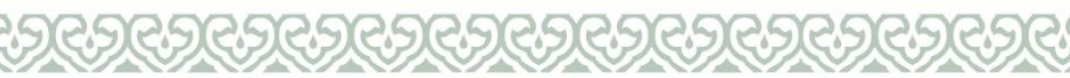

Рецензии и обзоры

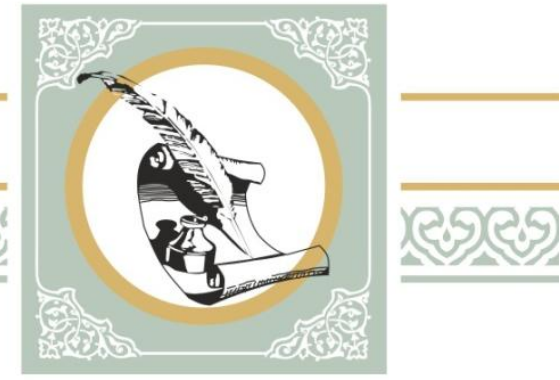

\title{
FROM STRUCTURE TO SYSTEM (REVIEW OF THE BOOK BY JEWANSKI, J., SAKHABIEV, R., MAXIMOVA A. SYNÄSTHESIEFORSCHUNG AM "PROMETHEUS" IN KAZAN, RUSSLAND. EINE BIBLIOGRAPHIE DER 18 KONGRESSBERICHTE 1967-2015. KASSEL UNIVERSITY PRESS GMBH, KASSEL, 2019. 365 P.)
}

\author{
Anastasia Borisovna Maksimova, \\ Head of the "Galeev-Prometheus" Foundation, \\ Apt. 301, 34 Fatykh Amirkhan Str., Kazan, 420132, Russian Federation, \\ amaximova@list.ru.
}

\begin{abstract}
The article reviews the bibliographic publication "Research on Synesthesia in 'Prometheus', Kazan (Russia)". The review briefly systematizes the data on the history of the study of the synesthesia phenomenon conducted under the guidance of Prof. Bulat Galeev (1940 - 2009). The article proves that the bibliographic analysis, carried out by the authors of the publication, is one of the important steps leading to the creation of the planned research laboratory where the multifaceted "Prometheans" scientific heritage will rightfully become a part of the world synesthetic context on the new technological platform.
\end{abstract}

Key words: Bulat Galeev, design bureau "Prometheus", Kazan, synesthesia, bibliographic edition.

Today, it is impossible to collect and summarize scientific information, to create a relatively complete picture from a mosaic of facts without using bibliographic reviews, bulletins, indexes, databases and search engines. Compiling an extended bibliographic publication on one topic, describing articles published by one team of researchers, diachronously and with a great historical perspective, is initially a serious and laborious mission. This is exactly the task set by the authors of the book in German recently published in Germany, its title reading as follows: "Research on Synesthesia in the 'Prometheus', Kazan, Russia. The bibliography of 18 conference proceedings (1967-2015)". This is the first large-scale work, covering Soviet and Russian approaches to the study of the phenomenon of intermodal and intersensory connections, its striking manifestation being "color hearing". Lasting for more than 50 years, this has been the only long-term synesthesia research project in the world holding regular scientific congresses. The information about this publication is included 
in the list of the German national bibliography, it is available in the search engine of the German National Library and for ordering on the Amazon platform. The publication of this work was made possible due to the support of the Austrian Research Foundation. A bibliographic index of all articles is given in German and Russian, with transliteration in Latin.

The publication consists of materials for specialized research and practice conferences, prepared by scholars from different parts of the country. The conferences were held in Kazan and they brought together researchers from different scientific areas. These forums became a center of attraction and a platform for heated discussions, fruitful dialogues about the nature of intersensual connections, about their influence on the work of artists and composers, about universally significant associations between sound and light / color.

In this country, the systematic study of the synesthesia phenomenon was initiated by Bulat Makhmudovich Galeev (1940 - 2009), Professor, Doctor of Philosophy, Corresponding Member of the Academy of Sciences of the Republic of Tatarstan, the author of 18 monographs and more than 800 articles. The scholar was the head and ideological leader of the first students' design bureau "Prometheus" at Kazan Aviation University, later he was the director of the Joint Research Institute of Experimental Aesthetics "Prometheus" at the Academy of Sciences of the Republic of Tatarstan [Nigmatullina]. B. Galeev and his fellow-Prometheans devoted their humanitarian philosophical works to the development of art in the context of technological progress; their studies were directly related to the practical technical developments in the field of audiovisual and computer art, music of light and electronics. In the 1960s -1970s, with the development of cybernetics and electronics, controlled light of music, used in concert activities, in cinematography, design and architecture, became both a marker of pop culture and a kind of "reference point" for the marginal, video and technoart, for electronic music, mapping, generative and computer art, which developed later.

It was precisely the fact that not only theoretical and art related issues, but also purely technical and applied problems were discussed at the Kazan research and practice seminars and conferences that attracted participants. Kazan scientific meetings were attended by psychologists and composers, art critics and engineers, philosophers and philologists, cultural scientists and historians, mathe- maticians and even astronauts, which is the evidence of the interest in the non-classical trend within the framework of the dominant doctrine. Interdisciplinarity, the focus on practice, an opportunity to learn about the latest developments in these areas taking place abroad (which traditionally received attention) gave impetus to everyone involved.

An international team of authors, who have repeatedly participated in these symposia themselves, devoted this study to a bibliographic analysis and description of all theses, materials of reports and articles of the conferences, organized by the "Prometheus" team in Kazan from 1967 to 2015. Having direct access not only to the conference proceedings, but also to the archival documents, correspondence and drafts, the compilers of the bibliographic manual tried to restore the personal and thematic catalog as fully as possible. The publication presents the analysis of 1212 articles, 3720 pages in number, structurally subsumed in several sections.

Given that the alternative themes "synesthesia", "music of light", "color hearing" and partly "synthesis of arts" were by no means among foreground ones in Soviet aesthetics, it might be of considerable interest to get acquainted with the practical and theoretical experiences of the team, which studied this issue purposefully and comprehensively. Moreover, our contemporary artists, whose experimental work, copying Western models, sometimes does not take into account the rich heritage in their "homeland", feel the need to comprehend the pioneering developments of Russian scholars in audiovisual and technological art. Even more sad is the fact that most of the publications, described in the bibliographic edition, were not available outside the country due to the language barrier and due to the fact that the Soviet and Russian collections could not appear on the international market. Despite the fact that the "Prometheus" practical developments - its music of light films, video installations and objects of light - were sometimes exhibited at festivals abroad, still the articles and conference materials remained unknown to Western researchers before this publication. The fact that this book can be purchased on the Internet platform and the fact that the material in the main catalog is presented in three versions suggest that the audience of readers will not be limited to the Russian-speaking scientific and artistic community.

Based on the above, significant results of the work include the fact that it is for the first time that 
a detailed bibliographic description of articles and materials on this interdisciplinary topic has been systematized, preliminary statistically assessed and documented. This means new data have been introduced into scientific circulation. So far, there has not yet been such a detailed presentation with clarification notes on authors and cities, with explanatory articles and graphs, neither in Russian, nor in the foreign bibliography ${ }^{1}$. It would be inaccurate to attribute to serious bibliographic descriptions those brief reviews of the conference proceedings that were regularly published by B. Galeev in "Leonardo", the American indexed journal on science, technology and art, in which he was a member of the editorial board for 30 years.

As for the structure of the monograph, we can note its logic and consistency, as well as the authors' desire to fully present the geography of the conference participants, the leading authors and, in general, to familiarize the readers with the creativity and aesthetic searches of the Prometheus team and its leader.

After a short introduction comes an 80-page essay, which describes, with illustrations and explanations, the stages of the team's activity [Jewanski, Sakhabiev, Maximova, pp. 12-94]. Here is a preliminary short overview with statistics and graphs for all conferences. The tables summarize information on the number of articles and pages in each collection of articles, on their circulation and the number of participants from the far abroad, on the most actively published Russian-speaking authors, on the cities from which the conference participants often came from. Such a comprehensive and thorough analysis with graphical calculations is not typical of bibliographic works published in Russia; however, it is very convenient for researchers, as it gives a generalized understanding and accurate numerical parameters according to various criteria. The discussion of different interpretations of the concept "synesthesia" is a fundamentally important point in this essay as well as the interdependent reception of Western and Russian approaches to the study of this phenomenon. The essay ends with a list of used literature, consisting of 84 articles on the team's history and work.

After a well-grounded representation of the source base, there follows a "Review of the Collections of Articles by Sections and by the Number of Articles" and a "Detailed Index of the Contents of

\footnotetext{
${ }^{1}$ It is worth noting that the bibliographic data was also collected by the members of the team ["Music of light, synesthesia, "color hearing"].
}

the Conference Proceedings". Referring to them, it is easy to find out that the maximum number of articles was published in 1979 - 116 and in 1987 110; the largest number of sections was in 2010 and in 2012 - six each time. The second mentioned index, in more detail - on 74 pages, gives a list of all the tables of contents of eighteen collections of articles in German. Here, in addition to the title of the articles, appendices, introductions and supplementary materials, published in some collections, are indicated.

The "Detailed Index ..." is followed by a personal catalog, which includes a list of 707 authors. The researchers, who most actively published their articles in the conference proceedings, were: the editor of most collections and the team leader B. M. Galeev (110 articles out of 1212), R. F. Saifullin (45), I. L. Vanechkina (44), and V. P. Bukatin (36). Further comes the distribution by cities and countries, from which we learn that scientists from 89 cities, including settlements of the former USSR and 11 foreign countries, came to Kazan. Most often, representatives of Moscow and Leningrad / St. Petersburg took part in the Kazan forums.

The personal catalog is followed by the actual bibliographic index of all articles according to the alphabetical list of authors in German and Russian with transliteration in Latin. The index spans 110 pages of the book. At the end, the appendices are given - a "List of monographs, published by B. M. Galeev and "Prometheus"' (47 titles), and a list of titles of his works in foreign publications (107 articles). The book ends with a page-by-page index of the concepts and terms mentioned in this work.

The style of presentation of the material meets the requirements for this kind of literature, while detailed explanations of the techniques, used to arrange information and abbreviations, help readers to understand the array of facts and lists. Undoubtedly, the publication is characterized by strict logic, consistency, coherence and accuracy. This approach allows a wide range of specialists to effectively use the bibliographic guide. The evidence, reliability and concreteness of the data presented can serve as the basis for a systematic study of a number of interdisciplinary topics: synesthesia, color hearing, synthesis of arts, B. Galeev's work, the Prometheus team, etc.

Summing up, we would like to note that the chronological, territorial and aspect coverage of bibliographic objects, combined thematically and in retrospect, grouped alphabetically, by subject and by author, is an expanded search base, which 
can subsequently be easily transformed into an electronic format, and the existing structure will form the basis for system calls. This is a prospect for further research.

The fact that the book was published in German somewhat limits the number of readers in Russia; on the other hand, it raises the awareness of Western scholars about the Kazan phenomenon. This bibliographic analysis is one of the important steps towards the creation of a planned research laboratory, where the multifaceted scientific heritage of the "Prometheans" will rightfully become a part of the global synesthetic context on the new technological platform.

\section{References}

Jewanski, J., Sakhabiev, R., Maximova, A. (2019). Synästhesieforschung am „Prometheus“ in Kazan,
Russland. Eiтe Bibliographie der 18 Kongressberichte 1967-2015. 365 p. Kassel university press GmbH, Kassel. (In German)

Nigmatullina, Yu. G. (2020). Vklad Bulata Galeyeva v kompleksnoe izuchenie khudozhestvennogo tvorchestva [Bulat Galeev's Contribution to the Comprehensive Study of Artistic Works].Tatarica. No. 2 (15), pp. 105-117. (In Russian)

Svetomuzyka, sinesteziia, "tsvetnoy slukh": annotirovannyi bibliograficheskii ukazatel' (Rossiia, 1742-2002) (2006) [Music of Light, Synesthesia, "Color Hearing": An Annotated Bibliographic Index (Russia, 1742-2002)]. Akad. nauk Respubliki Tatarstan, Kazanskii gos. tekhnicheskii un-t im. A. N. Tupoleva, NII eksperimental'noi estetiki "Prometei"; sost. ukaz. i avt. annot. B. Galeev. 169 p. Kazan', FEN. (In Russian)

\title{
ОТ СТРУКТУРЫ К СИСТЕМЕ (РЕЦЕНЗИЯ НА КНИГУ JЕWАNSKI, J., SAKHABIEV, R., MAXIMOVA A. SYNÄSTHESIEFORSCHUNG AM «PROMETHEUS» IN KAZAN, RUSSLAND. EINE BIBLIOGRAPHIE DER 18 KONGRESSBERICHTE 1967-2015. KASSEL UNIVERSITY PRESS GMBH, KASSEL, 2019. 365 S.)
}

\author{
Анастасия Борисовна Максимова, \\ Фонд «Галеев-Прометей», \\ Россия, 420132, г. Казань, ул. Фатыха Амирхана, д. 34, кв. 301, \\ amaximova@list.ru.
}

\begin{abstract}
В статье речь идет о библиографическом издании «Исследование синестезии в „Прометее“ в Казани (Россия)». В рецензии систематизирован материал по истории изучения феномена синестезии под руководством профессора Булата Галеева (1940-2009). Доказано, что проведенный составителями издания библиографический анализ является одним из важных шагов к созданию планируемой исследовательской лаборатории, где многогранное научное наследие «прометеевцев» на новой технологической платформе по праву станет частью мирового синестетического контекста.
\end{abstract}

Ключевые слова: Булат Галеев, конструкторское бюро «Прометей», Казань, синестезия, библиографическое издание.

Без библиографических обзоров, бюллетеней, указателей, баз данных и поисковых систем собрать и обобщить научную информацию, создать из мозаики фактов относительно полную картину сегодня немыслимо. Составление расширенного библиографического издания по одной теме, описывающего статьи, изданные одним коллективом, диахронно, с большой исторической перспективой, - это изначально серьезная и трудоемкая миссия. Именно такую задачу поставили себе авторы вышедшей недавно в Германии на немецком языке книги, название которой на русском звучит следующим образом: «Исследование синестезии в „,Прометее“» в Казани (Россия)». Библиография 18 сборников конференций (1967-2015)». Это первая масштабная работа, освещающая советские и российские подходы в изучении феномена межмодальных и межсенсорных связей, ярким проявлением которого является «цветной слух». И это единственный в мире долгосрочный, длящийся уже более 50 лет проект по исследованию синестезии, в рамках которого проводятся регулярные научные конгрессы. 
Информация об издании вошла в перечень немецкой национальной библиографии, доступна в поисковике национальной библиотеки ФРГ и для заказа на платформе Amazon. Публикация этого издания стала возможной благодаря поддержке Австрийского фонда содействия научным исследованиям. Библиографический указатель всех статей дается на немецком и русском языке, с транслитерацией на латинице.

Издание состоит из материалов, подготовленных учеными из разных уголков страны для специализированных научнопрактических конференций, проводимых в Казани и объединявших специалистов разных дисциплин. Эти форумы стали центром притяжения и площадкой для острых дискуссий, плодотворных диалогов о природе межчувственных связей, об их влиянии на творчество художников и композиторов, об общезначимых ассоциациях между звуком и светом / цветом.

Инициатором планомерного изучения феномена синестезии в нашей стране являлся Булат Махмудович Галеев (1940-2009), професcop, доктор философских наук, членкорреспондент Академии наук РТ, автор 18 монографий и более 800 статей. Ученый был руководителем и идейным лидером сначала студенческого конструкторского бюро «Прометей» в стенах казанского авиационного вуза, а потом директором Совместного научноисследовательского института экспериментальной эстетики «Прометей» при АН РТ [Нигматуллина]. Гуманитарные философские штудии Б. Галеева и его соратников«прометеевцев» о путях развития искусства в условиях технологического прогресса были непосредственно связаны с практическими техническими разработками в сфере аудиовизуального и компьютерного искусства, светомузыки и электроники. С развитием кибернетики и электроники в 1960-70-х годах прошлого века управляемая светомузыка в концертной деятельности, в кино, дизайне и архитектуре становится одновременно и маркером попкультуры, и своеобразной «точкой отсчета» для маргинальных, развившихся позже видео- и техноарта, электронной музыки, мэппинга, генеративного и компьютерного искусства.

Привлекательность казанских научнопрактических семинаров-конференций была именно в том, что здесь обсуждались не только теоретические и искусствоведческие, но и сугубо технические и прикладные вопросы. Участие в казанских научных встречах психо- логов и композиторов, художников и инженеров, философов и филологов, культурологов и историков, математиков и даже космонавтов доказывает, что интерес к неклассическому в рамках главенствующей доктрины направлению был необычайный. Междисциплинарность, ориентированность на практику, знакомство с новейшими зарубежными разработками в указанных областях (чему традиционно уделялось внимание) давали импульсы для всех участвующих.

Библиографическому анализу и описанию всех тезисов, материалов докладов и статей конференций, организованных коллективом «Прометей» в Казани с 1967 по 2015 г., и посвящено исследование международного коллектива авторов, которые сами неоднократно принимали участие в этих симпозиумах. Имея непосредственный доступ не только к самим сборникам конференций, но и к архивным документам, переписке и черновикам, составители библиографического пособия постарались максимально полно восстановить персональный и тематический каталог. В издании представлен анализ 1212 статей, объемом 3720 страниц, которые распределены структурированно по нескольким разделам.

Учитывая, что альтернативные темы «синестезия», «светомузыка», «цветной слух» и отчасти «синтез искусств» являлись в советской эстетике отнюдь не приоритетными, можно утверждать, что знакомство с практическим и теоретическим опытом коллектива, целенаправленно и всесторонне занимавшегося этой проблематикой, представляет несомненный интерес. Более того, в осмыслении отечественных пионерских разработок в аудиовизуальном и технологическом искусстве нуждаются и современные художники, эксперименты которых, копируя западные образцы, подчас не учитывают богатейшее наследие, имеющееся в «своем отечестве». Еще печальней тот факт, что большая часть публикаций, описанных в библиографическом издании из-за языкового барьера, из-за того что советские и российские сборники не могли реализовываться на международном рынке, не были доступны за пределами страны. И если практические разработки «Прометея» - светомузыкальные фильмы, видеоинсталляции и световые объекты - хоть иногда выставлялись на фестивалях за границей, то статьи и материалы конференций оставались до этого издания неизвестными для западных исследователей. Тот факт, что эту кни- 
гу можно приобрести на интернет-платформе, и то, что материал в основном каталоге представлен в 3 вариантах, дают основание полагать, что аудитория читателей не ограничится русскоговорящим научным и художественным сообществом.

К значимым результатам работы, исходя из сказанного выше, можно отнести то, что впервые проведена систематизация, предварительная статистическая оценка, документация и подробное библиографическое описание статей и материалов по междисциплинарной теме. Это означает введение в научный оборот нового массива данных. Такого детального представления, с уточнениями по авторам и городам, с пояснительными статьями и графиками, до настоящего времени в отечественной и тем более в зарубежной библиографии ${ }^{1}$ не было. К серьезному библиографическому описанию неточно относить краткие рецензии на сборники конференций, регулярно публиковавшиеся Б. Галеевым в американском индексируемом журнале о науке, технологии и искусстве «Leonardo», членом редколлегии которого он являлся на протяжении 30 лет.

Обращаясь к структуре монографии, можно отметить ее логичность и последовательность, а также стремление авторов предельно полно представить географию участников конференций, ведущих авторов, расширить знакомство с творчеством и эстетическими поисками коллектива «Прометей» и его руководителя.

После краткого вступления размещается 80-страничный очерк, в котором с иллюстрациями и пояснениями описываются этапы деятельности коллектива [Jewanski, Sakhabiev, Maximova, c. 12-94]. Здесь представлен предварительный краткий обзор со статистическими данными и графиками по всем конференциям. В таблицах сведена информация по количеству статей и страниц в каждом сборнике, по тиражу и количеству участников из дальнего зарубежья, по наиболее активно публикующимся в этих конференциях русскоговорящим авторам, по городам, из которых часто приезжали участники конференций. Такой всесторонний скрупулезный анализ с графическими выкладками не типичен для публикуемых в России библиографических работ, однако очень удобен для исследователей, так как дает обобщенное понимание и точные цифровые параметры по раз-

\footnotetext{
${ }^{1}$ Стоит отметить, что сбором библиографических данных занимались и сотрудники самого коллектива [Светомузыка, синестезия, «цветной слух»].
}

ным критериям. Принципиально важным пунктом в указанном очерке является рассмотрение вопроса об особенностях трактовки понятия «синестезия» и о взаимообусловленной рецепции западных и российских подходов в изучении этого феномена. Завершает очерк перечень использованной литературы из 84 статей по истории и творчеству коллектива.

После фундированной репрезентации источниковой базы следует «Обзор сборников по секциям и количеству статей в каждом из них» и «Детальный указатель содержания сборников конференций». Так, без труда выясняется, что максимальное количество статей было опубликовано в 1979 г. - 116, а также в 1987 г. - 110, наибольшее количество секций было в 2010 и 2012 гг. - по шесть. Второй упомянутый указатель уже более подробно - на 74 страницах дает перечень всех оглавлений 18 сборников на немецком языке. Здесь указаны, помимо названия статей, приложения, введения и дополнительные материалы, которые публиковались в некоторых сборниках.

За «Детальным указателем...» следует персональный каталог, который включает в себя перечень из 707 авторов. Наиболее активно публиковался в сборниках конференций редактор большинства изданий и руководитель коллектива Б. М. Галеев (110 из 1212), Р. Ф. Сайфуллин (45), И. Л. Ванечкина (44) и В. П. Букатин (36). Далее представлено распределение по городам и странам, из которого выясняется, что в Казань приезжали ученые из 89 городов, включая населенные пункты бывшего СССР, и 11 стран дальнего зарубежья. Чаще всего принимали участие в казанских форумах представители Москвы и Ленинграда / СанктПетербурга.

После персонального каталога размещен библиографический указатель всех статей по алфавитному списку авторов на немецком и русском языках с транслитерацией на латинице. Указатель занимает 110 страниц книги. В завершение даются приложения: список монографий, изданных Б. М. Галеевым и «Прометеем» (47 наименований), и перечень названий публикаций ученого в зарубежных изданиях (107 статей). Завершается книга постраничным указателем упоминаемых в издании понятий и терминов.

Стиль изложения материала соответствует требованиям, предъявляемым к такого рода литературе, а подробные объяснения используемых приемов расположения информации и со- 
кращений помогают читателям разобраться в массиве фактов и перечней. Несомненно, издание обладает строгой логичностью, последовательностью, связностью и точностью. Такой подход позволяет эффективно использовать библиографическое пособие широкому кругу специалистов. Доказательность, достоверность и конкретность приведенных данных может послужить базой для системного изучения ряда междисциплинарных тем: синестезии, цветного слуха, синтеза искусств, творчества Б. М. Галеева, коллектива «Прометей» и многих других.

Подытоживая, отметим, что хронологический, территориальный и видовой охват объектов библиографирования, объединенных тематически и в ретроспективе, сгруппированных алфавитно, предметно и по авторам, представляет собой расширенную поисковую базу, которая впоследствии может быть легко трансформирована в электронный формат, а имеющаяся структура может стать базой для системных обращений. Это является ближайшей перспективой исследования.

То, что книга выпущена на немецком языке, несколько ограничивает количество читателей в России, но, с другой стороны, повышает информированность западных ученых о казанском феномене. Проведенный библиографический анализ - один из важных шагов к созданию планируемой исследовательской лаборатории, где многогранное научное наследие «прометеевцев» на новой технологической платформе по праву станет частью мирового синестетического контекста.

\section{Литература}

Нигматуллина Ю. Г. Вклад Булата Галеева в комплексное изучение художественного творчества // Tatarica. 2020. № 1 (15). C. 105-117.

Светомузыка, синестезия, «цветной слух»: аннотированный библиографический указатель (Россия, 1742-2002) / Акад. наук Республики Татарстан, Казанский гос. технический ун-т им. А. Н. Туполева, НИИ экспериментальной эстетики «Прометей»; сост. указ. и авт. аннот. Б. Галеев. Казань: ФЭН, 2006. 169 с.

Jewanski, J., Sakhabiev, R., Maximova A. Synästhesieforschung am «Prometheus» in Kazan, Russland. Еіте Bibliographie der 18 Kongressberichte 1967-2015. Kassel university press GmbH, Kassel, 2019. $365 \mathrm{~s}$.

\title{
СТРУКТУРАДАН СИСТЕМАГА JEWANSKI, J., SAKHABIEV, R., MAXIMOVA A. SYNÄSTHESIEFORSCHUNG AM «PROMETHEUS»IN KAZAN, RUSSLAND. EITE BIBLIOGRAPHIE DER 18 KONGRESSBERICHTE 1967-2015. KASSEL UNIVERSITY PRESS GMBH, KASSEL, 2019. 365 S. КИТАБЫНА БӘЯЛӘМӘ
}

\author{
Анастасия Борисовна Максимова, \\ «Галеев-Прометей» фонды, \\ Россия, 420132, Казан ш., Фатих Әмирхан пр., 34 йорт, 301 кв, \\ amaximova@list.ru.
}

\begin{abstract}
Мәкаләдә «Казандагы (Россия) «Прометей»да синестезияне тикшерү» дип аталган биобиблиографик басма хакында сүз бара. Рецензиядә профессор Булат Галиев $(1940$ - 2009) житәкчелегендә синестезия феноменын өйрәнү тарихы турындагы материал кыскача системага салып бирелә. Басманы төзүчеләр тарафыннан үткәрелгән библиографик анализның планлаштырылган тикшеренү лабораториясен төзү юлында мөһим бер адым булачагы дәлилләнә. Яңа технологик платформада «прометейчыларның» күпьяклы фәнни мирасы хаклы рәвештә дөньякүләм синестетик контекстның бер өлешенә әйләнәчәк.
\end{abstract}

Төп төшенчәләр: Булат Галиев, “Прометей” конструкторлык бюросы, Казан, синестезия, биобиблиографик басма. 